tification for controlling spread of vancomycin-resistant Enterococcus faecalis isolates. J Clin Microbiol 1996;34:2129-2132.

4. Boyce JM, Opal SM, Chow JW, Zervos MJ, Potter-Bynoe G, Sherman $\mathrm{CB}$, et al. Outbreak of multidrug-resistant Enterococcus faecium with transferable $v a n \mathrm{~B}$ class vancomycin resistance. I Clin Microbiol 1994;32:1148-1153.

5. Handwerger S, Raucher B, Altarac D, Monka J, Marchione S, Singh KV, et al. Nosocomial outbreak due to Enterococcus faecium highly resistant to vancomycin, penicillin, and gentamicin. Clin Infect Dis 1993;16:750-755.

6. Karanfil LV, Murphy M, Josephson A, Gaynes R, Mandel L, Hill BC, et al. A cluster of vancomycin-resistant Enterococcus faecium in an intensive care unit. Infect Control Hosp Epidemiol 1992;13:195-200.

7. Noskin GA, Stosor V, Cooper I, Peterson LR. Recovery of vancomycin resistant enterococci on fingertips and environmental surfaces. Infect Control Hosp Epidemiol 1995; 16:577-581.

8. Livornese LL.Jr, Dias S, Samel C, Romanowski B, Taylor S, May P, et al. Hospital-acquired infection with vancomycin-resistant Enterococcus faecium transmitted by electronic thermometers. Ann Intern Med 1992;117:112-116.

9. Porwancher R, Sheth A, Remphrey S, Taylor E, Hinkle C, Zervos M. Epidemiological study of hospital-acquired infection with vancomycinresistant Enterococcus faecium: possible transmission by an electronic ear-probe thermometer. Infect Control Hosp Epidemiol 1997;18:771-774.

10. Morris JG Jr, Shay DK, Hebden JN, McCarter RJ Jr, Perdue BE, Jarvis W, et al. Enterococci resistant to multiple antimicrobial agents, including vancomycin: establishment of endemnicity in a university medical center. Ann Intern Med 1995;123:250-259.

11. Facklam RR, Collins MD. Identification of Enterococcus species isolates from human infections by a conventional test scheme. J Clin Microbiol 1989;27:731-734.

12. National Committee for Clinical Laboratory Standards. Methods for Dilution Antimicrobial Susceptibility Tests for Bacteria That Grow Aerobically. 4th ed. Approved Standard. Document M7-A4. Villanova, PA: NCCLS; 1997.

13. Hospital Infection Control Practices Advisory Committee. Recommen- dations for preventing the spread of vancomycin resistance. Infect Control Hosp Epidemiol 1995;16:105-113.

14. Pitcher DG, Saunders NA, Owen RJ. Rapid extraction of bacterial genomic DNA with guanidium thiocyanate. Letters in Applied Microbiology 1989;8:151-156.

15. Savor C, Pfaller MA, Kruszynski JA, Hollis RJ, Noskin GA, Peterson LR. Comparison of genomic methods for differentiating strains of Enterococcus faecium: assessment using clinical epidemiologic data. $J$ Clin Microbiol 1998;36:3327-3331.

16. Rutala WA. APIC guidelines for the selection and use of disinfectants. Am J Infect Control 1996;24:313-342.

17. Clabots CR, Johnson S, Bettin KM, Mathie PA, Mulligan ME, Schaberg DR, et al. Development of a rapid and efficient restriction endonuclease analysis (REA) typing system for Clostridium difficile and correlation with other typing systems. J Clin Microbiol 1993;31:1870-1875.

18. Bonten MJM, Hayden MK, Nathan C, van Voorhis J, Matushek M, Slaughter S, et al. Epidemiology of colonization of patients and environment with vancomycin-resistant enterococci. Lancet 1996;348:1615-1619.

19. Dunne WM Jr, Wang W. Clonal dissemination and colony morphotype variation of vancomycin-resistant Enterococcus faecium isolates in metropolitan Detroit, Michigan. J Clin Microbiol 1997;35:388-392.

20. Perlada DE, Smulian AG, Cushion MT. Molecular epidemiology and antibiotic susceptibility of enterococci in Cincinnati, Ohio: a prospective citywide survey. I Clin Microbiol 1997;35:2342-2347.

21. Fridkin SK, Yokow DS, Whitney CG, Onderdonk A, Hooper DC. Epidemiology of a dominant clonal strain of vancomycin-resistant Enterococcus faecium at separate hospitals in Boston, Massachusetts. Clin Microbiol 1998;36:965-970.

22. Boyle JF, Soumakis SA, Rendo A, Herrington JA, Gianarkis DG, Thurberg BE, et al. Epidemiologic analysis and genotypic characterization of a nosocomial outbreak of vancomycin-resistant enterococci. $J$ Clin Microbiol 1993;31:1280-1285.

23. Chow JW, Kuritza A, Shlaes DM, Green M, Sahm DF, Zervos MJ. Clonal spread of vancomycin-resistant Enterococcus faecium between patients in three hospitals in two states. J Clin Microbiol 1993;31:1609-1611.

\title{
Knowledge, Attitudes, and Behavior of Operating Room Staff
}

\section{Gina Pugliese, RN, MS Martin S. Favero, PhD}

Angelillo and coinvestigators from the Medical School, University of Catanzaro Magna, Graecia, Italy, have reported on a study that examined the disinfection and sterilization practices used by hospital operating rooms and evaluated the knowledge, attitudes, and behavior of nursing staff with regard to infection control. Of the 216 nurses who responded, knowledge concerning such practices was not consistent, since $10 \%$ did not believe that items should be rinsed in water after contact with glutaraldehyde and more than $25 \%$ thought that 10 -minute contact time provided ster- ilization. Almost all were aware that improper practices increased the risk of nosocomial infections in patients. Nurses in orthopedic surgery had a significantly lower level of knowledge compared with others. The great majority of nurses agreed that guidelines for disinfection and sterilization practice should be maintained and applied.

With regard to the use of surgical instruments, the majority used steam or dry-heat sterilizers for the appropriate time and temperature. Glutaraldehyde was used by $95 \%$ to sterilize endoscopes, but at different temperatures and times of exposure. Similar procedures were reported as used for laryngoscopes, although a higher percentage used heat steriliza- tion. Only $38 \%$ routinely used all barrier techniques (gloves, masks, and protective eyewear). Predictors for the routine use of all barrier techniques included attendance at continuing education courses on nosocomial infections, nurses who were male, and nurses involved in orthopedic operations. Data support the need for finding and implementing interventions related to the prevention of hospital infection activities, to motivate nurses to use the correct procedures as a routine.

FROM: Angelillo IF, Mazziotta A, Nicotera G. Nurses and hospital infection control: knowledge, attitudes and behaviour of Italian operating theatre staff. $J$ Hosp Infect 1999;42:105-112. 